\title{
How Do Human Resource Management Practices Predict Employee Turnover Intentions: An Empirical Survey of Teacher Training Colleges in Kenya
}

\author{
Kyalo Abigail Manthi ${ }^{1}$, James M. Kilika ${ }^{2} \&$ Linda Kimencu $^{2}$ \\ ${ }^{1}$ Machakos Teachers Training College, Kenya \\ ${ }^{2}$ Department of Business Administration, Kenyatta University, Kenya \\ Correspondence: James M. Kilika, Department of Business Administration, Kenyatta University, Kenya. \\ Email:kilikam3@yahoo.com
}

Received: June 20, 2018

Accepted: July 15, 2018

Online Published: July 23, 2018

doi:10.5430/ijba.v9n4p201

URL: https://doi.org/10.5430/ijba.v9n4p201

\begin{abstract}
This study sought to establish how Human Resource Management practices predict tutor turnover intentions in primary Teacher Training colleges (PTTCs) in Kenya. The objectives of the study were: to establish the influence of Training, Compensation, Career development and Performance management on tutor turnover intentions in PTTCs in Kenya. The scope of the study was the Nairobi Metropolitan region. Multi stage sampling was used to obtain a sample size of 152 respondents where the actual response rate was $74.3 \%$. The findings of the study showed that training, compensation, career development and performance management were poorly practiced and that they significantly and negatively predict tutor turnover intentions in PTTCs as they collectively accounted for $28 \%$ variation in the experienced turnover intentions among the tutors. The findings raise both theoretical and practical implications for underpinning HRM practice, behavioral science theories and personnel administrative responsibilities to college principals respectively. The study calls on future research to consider the contingent effects of the tutors' demographic characteristics and the contextual factors surrounding HRM Practice in the Colleges.
\end{abstract}

Keywords: human resource management practices, turnover intentions, primary teacher training colleges

\section{Introduction}

It is globally acknowledged that one of the aims of Human Resource Management (HRM) practice is to promote commitment that strengthens an individual's identification with, and involvement in a particular organization and especially in the teaching workforce (Wachira, 2010). According to Wright, Gardner and Allen (2005), HRM practices are important pillars in building and maintaining trust in employees for they shape the employment relationships between the employee and the employer. Employee turnover has become a challenge to many organizations in the management of employees (Foon, Chee-Leong, \& Osman, 2010). Price and Mueller (1981) grouped turnover in to two categories namely; voluntary and involuntary turnover. The two authors posit that voluntary turnover occurs when an employee willingly makes a personal decision to leave an organization, while involuntary turnover occurs when an employer decides to dismiss an employee from the organization. Kaur, Mohindru and Pankaj (2013) state that involuntary turnover has been argued to be generally good for an organizational interest while voluntary turnover is seen as destructive to organizational stability. Some of the reasons as to why employees voluntarily leave organizations include; lack of job satisfaction, low satisfaction with an employer, low levels of promotion and growth opportunities, greener pastures in other organizations, resistance to organizational changes or restructuring among others (Kaur et al, 2013).

Johnsrud and Rosser (2002) hold the view that it may be practically difficult to study actual turnover behavior, because it is hard to trace the whereabouts of the employees who have left and in addition their response rate to surveys is usually low. It is for this reason that Fang (2001) argued that turnover intention can be safely used as a good measure of employee turnover. Based on the arguments of the attitude-behavior theory by Fishbein and Ajzen (1975) that one's intention to perform a specific behavior is a closer predictor of that behavior, it has been suggested that turnover intention rather than actual turnover should be seen as the best predictor of turnover. 
Research on turnover intention attracts interest due to its psychological and economic dimensions as well as its organizational significance. It is imperative therefore for HRM managers to understand that there are several factors inherent to counter staff intentions to leave or even the actual turnover. One theory specifies that an employees' decision to resign is influenced by two factors; their "perceived ease of movement", which refers to the assessment of perceived alternatives or opportunity and "perceived desirability of movement", which is influenced for instance by job satisfaction (Morrell, Loan-Clarke \& Wilkinson, 2004; Abdullah, Bilau, Enegbuma, Ajagbe, Ali \& Bustani 2012). This suggests the need for a balance to be struck both for the organization and its employees in terms of inducements such as compensation, recognitions in career development and improved performance through training and performance management which ensures continued organizational efficiency. In general, when human resources are managed well by the organization, this lowers the tendency of the worker to leave and vice versa (Morrell et al., 2004).

Shasuzzoha and Shumon (2012) point out that when employees are not managed well by an organization, they are bound to look for greener pastures in other organizations and more so in the education sector. Teachers are a crucial component of an education system whose services are important due to their central role in education in the realization of educational goals in the world. Cushinery, (2011) notes that an effective and competent teacher needs to remain in the profession long enough to experience variation of circumstances and situations which nurtures their competences or excellence in teaching. Caillods (1989) asserts that the art of teaching is a developmental process which involves a complex set of skills many of which can only be well polished on uninterrupted job experience, therefore turnover deprives the teaching profession the skills that have been acquired over time. Turnover tends to be higher in an environment where employees feel undervalued or ignored and where they feel helpless or unimportant. Management policies can also affect the environment in basic ways such as whether employee benefits and incentives appear generous or stingy, or whether the company is responsive to employee's needs and wants.

Nasurdin, Hemdi and Guat (2008) posit that; how an organization manages its human resources (as reflected by its HRM practices) establishes the tone and conditions of the employee-employer relationship. When such relationship is seen as that of a social exchange (Blau, 1964) where the norm of reciprocity is central, employees would be more inclined to engage in positive work attitudes and behaviors. Thus, Human Resources Management practices can reduce employee turnover intentions through their contributions towards enhancing individual employee commitment. In the present study, with reference to gaps in extant literature, a number of HR practices such as compensation, employee training, career development and performance management have been proposed as possible predictors of employee turnover intentions among tutors in teacher training colleges in Kenya.

\subsection{Statement of the Problem}

Globally, the teaching profession suffers from high annual turnover intention rate standing at $45 \%$ (Oduor, 2015). In Kenya out of the 288,000 teachers employed by the Government, about 129,600 would wish to quit the profession despite the fact that teacher shortage stands at 66,708 (UNESCO, 2012; UNESCO, 2015). Empirical studies on turnover in Kenya have indicated that the low status, poor remuneration, constant ridicule by public and the mass media, lack of fringe benefits, overwork and deplorable working conditions have created a lot of despair amongst teachers (Nyambura, 2012). This has led to the movement of teachers to join other sectors of economy such as private firms, institutions of higher learning, the Ministry of Education and lately to the counties where terms of service are perceived to be more lucrative than what the employer, Teachers Service Commission (TSC) offers (Eshiwani, 1990; Oduor, 2015). Previous studies (Waititu 2013; Nyambura 2012; Masinde, Kwasira \& Cheruiyot 2014) have focused on turnover and overlooked the psychological orientations of the employee (turnover intentions) before the actual turnover which is not easy to measure because those who have left are hardly traceable and the response rate is in most cases low.

Researches on turnover intentions such as those of Mustafa (2016), Rafique and Muhammad (2016) and Muhammad and Faizuniah (2015) were done in western countries and other sectors of economy like the banking institutions, hotels, nursing among others thus do not explain the situation in the education sector. Therefore, it is not easy to generalize the findings from researches done in the Western context and the corporate world linking HRM practices and turnover intentions to the Kenyan education sector due to differences in national cultural orientations and sectoral diversity. The purpose of this study was to examine how Human Resource Management practices predict tutor turnover intentions in public primary teacher training colleges in the Nairobi Metropolitan Region in Kenya. The study selected four HRM practices: employee training, compensation, career development and performance management. 
The study is significant in a number of ways. First, the study contributes towards addressing the unresolved academic debate regarding the linkage between HRM Practices and the construct of turnover intention. The current state of literature indicates that the link between HRM practices and employee turnover intention in organizations still remains a puzzle to many managers. The current study approaches the investigation from a multidisciplinary based theoretical perspective to address the linkage using theories drawn from HRM and the behavioral sciences. Secondly, the study is undertaken in one of the key sectors of the economy considered to be at the core of national development. Given the nature of the job requirements for service providers in the teaching profession, addressing the construct of turnover intention provides critical information that decision makers will find useful in addressing the question of employee capability and competence as the previous studies and practice have shown that teachers require some reasonable duration of practice to gain the required competences that will drive performance of the sector. Thirdly, the study is important in continuing the series of studies that have attempted to study HRM from a developing country perspective where it has been noted that HRM Practices have been understudied. In such settings, it is of interest to scholars and practitioners to study HRM from a more robust theoretical underpinning so as to model relationships among attendant theoretical and contextual constructs to enhance a comprehensive understanding of HRM and its outcomes. The study builds on previous attempts by Mutiso and Kilika (2017); Kilika, K'Obonyo, Ogutu and Munyoki (2016); Kilika, Obonyo, Ogutu and Munyoki, (2013); Kilika, (2012); Walumbwa, Orwa, Wang and Lawler (2005) and applies conceptualization drawn not only from HRM but also input from the behavioral sciences.

\section{Literature Review}

\subsection{Theoretical Review}

The current study was anchored on the unfolding model of voluntary turnover, the universalistic theory and the social exchange theory. Lee and Mitchell (1994) in their unfolding Model of Voluntary Turnover argue that, the decisions that an employee makes before leaving an organization can take place in many different ways. They proposed that individuals follow psychological and behavioral paths when quitting. The decisions regarding which path they would follow are determined by what is referred to as a "shock" that causes a person to pause and think about the meaning of that event in relation to his or her job (Lee \& Mitchell, 1994). Based on this theory tutors pause and think before making a decision to leave teaching following an event that can act as a shock; which can either be availability of other job alternatives, job dissatisfaction, moving to join a spouse or even the birth of a child.

The universalistic theory also referred to as the "best" practice model, is based on the assumption that there is a set of superior/best HRM practices, and that adopting them will inevitably lead to superior organizational performance (Kochan \& Osterman, 1994; Pfeffer, 1994; Luthans \& Summer, 2005). The Universalistic approach to SHRM has been validated through several empirical studies in the developed countries (Liouville \& Bayad 1995; Barrette \& Simeus 1997; Berg, 1999). Every organization therefore should use those HRM practices that it deems best in the management of its employees. This study adopted HRM Practices based on the functional areas of HRM which depict the traditional model (The Michigan School) that seems to have been used in African countries and in the public sector in Kenya (MSPS, 2007). A review of the literature also demonstrates four common practices that have been consistently used by different scholars which are associated with employee behaviors such as performance, innovation, turnover, and retention among others encompassing performance appraisal, career management, reward management and training.

The social exchange theory argues that both parties to a relationship need to reach an agreement based on a comparison of how much something is going to cost relative to the level of reward or benefit that something will provide. Homans (1961) argued that in general, two or more parties try to get something that is of greater value to them than the cost they incur. It can therefore be deduced that a well-designed HRM system creates a continuing sequence of fair employer-employee transactions. Hence, it has been established that the social exchange theory consists of relationships which translate into trust, loyalty and mutual commitments of the parties over a period of time (Tanova \& Holtom, 2008). It is for this reason that tutors will compare the work they do with the benefits that they receive from the TSC and the Government and try to find out whether the current employment is a satisfying exchange relationship. When the exchange relationship is not fair to them, then the tutors will make a decision on whether to stay with the TSC or quit teaching. 


\subsection{Conceptual and Empirical Review}

\subsubsection{Turnover Intentions}

Employee turnover is one of the major problems that organizations are seriously addressing today because of its impact on organizational economic growth (Samuel \& Chipunza, 2013). This is because the loss of employees has significant consequences on the performance of an organization which are both tangible and intangible (Frank, Finnegan, \& Taylor, 2004; Tanova \& Holtom, 2008). The tangible consequences include the administrative expenses involved in recruitment, selection and training and development of new employees, while the intangible effects include the loss of employee morale, social capital and company memory (Morrell, Load-Clarke, \& Wilkinson, 2004). The intangible loss of skills, experience, and know-how of companies is more significant than the tangible costs of replacing employees because it could lead to lower levels of productivity and performance which may translate to low profits. It is for this reason that organizations need to understand the serious impact of employee turnover on organizations and device ways of retaining their current employees (Frank, et al., 2004; Tanova et al., 2008). Ongori, (2007) revealed that organizations that are not stable have shown a high degree of turnover intentions and employees are more likely to stay when there is a predictable work environment and vice versa. In situations where organizations are not stable, employees tend to quit and look for stable organizations because with stable organizations they would be able to predict their career advancement. He points out that a high labour turnover may mean poor state of HRM practice. Gaiduk, and Gaiduk (2009) observed that previous studies have found that employee intentions to quit/remain with an organization are influenced by three major groups of variables which include: employee demographic characteristics such as gender, age, position, level; the nature of an employee's current job; and adequate working arrangements including such aspects as the quality of current supervision, opportunities for promotion, available training, and quality of communication within the organization. From the employees' point of view, HRM practices are considered as the organization's efforts in supporting and enhancing their career development. Thus, HRM practices reflect the organization's concern for the well-being of its workers. According to Guest (1997), the more positive the HRM practices are experienced by employees in their employment, the more satisfied they become, and the better their psychological contract.

Although there has been a lack of consensus regarding a universal set of HRM practices, in many cases, certain practices such as employee training, employee compensation, career development and performance management have been frequently identified as HRM practices that improve the employee-employer relationship. Raigama (2010) attempted to answer the question of what determines people's intention to quit by investigating possible antecedents of employees' intentions to quit and found out that there are several reasons as to why people quit organizations which include but not limited to job related stress, lack of commitment in the organization, job dissatisfaction, a sense of powerlessness, locus of control and personal control. A study by Tumwesigye (2015) on Human Resource Management Practices and Turnover Intentions of University Employees in Uganda with 722 respondents both teaching and non-teaching staff of six universities demonstrated that a system of 8 human resources management practices (recruitment and selection, rewards and recognition, training and development, promotion opportunities, information sharing, participation in decision making, employment security and performance appraisal) was negatively related to turnover intentions among university employees while Suguna (2017) tested the influence of Human Resource Practices on Turnover Intention in a Telecommunication Company in Malaysia with a sample size of 162 employees from its branches across the Klang Valley area in Malaysia. The results showed that results oriented appraisals, training, job description and employment security significantly influenced employees' intention to leave the organization while internal career opportunity did not influence employees' intention to leave the organization.

Building on the arguments drawn from these scholars, HRM practices comprise of specific practices, formal policies and philosophies that are designed to attract, develop, motivate, and retain employees who ensure the effective functioning and survival of the organization. Thus the researchers postulated that four HRM practices will predict tutor turnover intentions in PTTCs in Kenya, namely training, compensation, career development and performance management.

\subsubsection{Training}

Sherman and Snell (1998) argued that effective training programs for employees have become increasingly vital to the success of any organization. Employee training is a very important HRM practice in any organization. According to Storey (2000) employee training is needed for the improvement of employee skills and knowledge which is necessary in job performance as well as strengthening desired values that are required in employees. Abbas (2015) noted that employees who spend more time in developing skills and concentrating on their occupational goals have 
less intention to withdraw from their occupation. Ceptureanu (2016) argues that training is a Human resource development activity that is aimed at improving the employees work performance by equipping them with effective and efficient skills needed for completing tasks. Ng'ethe, Iravo, and Namusonge (2012) noted that opportunities for training and career progression are some of the important reasons why employees stay in an organization and especially the young and enthusiastic employees. Thus organizations need to provide an organized training and relevant career paths for their employees. It is for this reason that tutors need to have competencies and especially core sets of knowledge and expertise that will enable them to pass on the desired competences to their learners. The only way to arrive at this is through having a dedicated training program that plays a central role to nurture and strengthen these competencies.

Nyakundi (2013) in a descriptive study with 126 teachers from private secondary schools in Kenya found that training and promotion were important HRM practices in the maintenance of teachers. In support, Victor, Patrice, and Karine, (2010) in their earlier study on influence of thirteen Human Resource Management practices on voluntary turnover rates while controlling for workplace size, found that employer-provided training is associated with high turnover. Michael (2010) in a study on the influence of HRM practices on job satisfaction, organizational commitment on intention to quit found that training and development had a positive influence on employee retention. The findings are supported by that of Marlize and Gilberto (2014) in their effort to find out whether Human Resource Management practices can reduce turnover among Brazilian private companies. The researchers found that companies intending to slow or reduce employee turnover need to invest in training and developing its employees while Mbugua (2015)'s study on 44 commercial banks in Kenya found that training, recruitment and performance management were positively related to employee retention. Further, Mustafa (2016) in an empirical study on the impact of employee training and innovation on turnover intention with 239 employees of service firms in Turkey found that innovation and training had a significant power in decreasing turnover. The reviewed extant literature shows that there is lack of research in teacher training colleges in Kenya on the role of training in addressing turnover. Therefore the current study used training as one of the constructs to predict turnover intention in PTTCs in Kenya.

\subsubsection{Compensation}

Employee compensation is a critical component of the employment relationship which includes all forms of incentives that are aimed at motivating employees to strive for higher levels of productivity. Every employee desires a compensation system that is fair and in line with their skills, experiences and knowledge. Hence, organizational management must take note that pay provides the tangible rewards to the employees for the services they offer, as well acts as a source of recognition and livelihood (Randy, Vivienne, \& Thomas, 2002). According to Nivethitha, Dyaram and Kamalanabhan (2014), pay is one of the major reasons for high employee turnover in organizations. In support, Bula (2012) in a study done in the sugar industry in Kenya found that salary was a major factor causing labour turnover. A study by Mrope and Bangi (2013) using a case study with a sample size of 96 employees from Kibaha District Council in Uganda using purposive and random sampling techniques found that incentives, allowances and per diems were management practices that lead to employee turnover. Evidently in a study by Waititu (2013) on analysis of factors influencing turnover of teachers in high schools with a sample of 136 teachers found that inadequate salary leads to high teacher turnover while Mensah (2014) in an empirical study examined the effects of HRM practices on the retention of employees in the banking industry in Accra, Ghana found that when compensation is not provided for, employees in the banks are likely to leave the organization. Given the aforementioned discussions on extant literature pertaining employee compensation and turnover intentions, compensation was adopted as the second construct in predicting turnover intention in this study.

\subsubsection{Career Development}

Chitalu (2011) asserts that one of the key factors of retention of skilled employees is the provision of development opportunities. Having a diversified and effective career structure is important in influencing employees' decision making regarding their choice to join, leave or remain in an organization (OECD, 2009). Every management needs to offer continuous assistance to the employees by giving them feedback on individual performance and also making sure they avail any relevant information from the organization about career opportunities, positions and vacancies that might be of interest to the employees and also encourage them to take personal responsibility for their own careers (Zandy, Leibowitz, \& Beverly, 1986). However, Sherman and Snell (1998) argue that significant career growth can only occur when individual contribution combines with organization opportunity. A study by Muliawan (2009) among Information System Auditors in the US revealed that professional growth in career progression was related to turnover intentions. Relying on this work, Ng'ethe, Iravo, and Namusonge (2012) argue that in order to 
reduce employee turnover, employees need to be provided with career development and career opportunity for growth while Garcia-Martine and Ify (2014) in their study on career development and turnover in Food and Beverage Industry with a sample of 400 U.S. employees found that training was related to turnover intent. In addition , Muhammad and Faizuniah (2015) in their research with a sample of 270 full time faculty members employed in different private universities of Pakistan using Structural equation modeling revealed that out of the four dimensions of career growth, only two dimensions, namely promotion speed and remuneration growth, have strong influence on turnover intention. Rafique and Muhammad (2016) in their study on determinants of teachers' turnover intention in Bahria Schools and Colleges at Karachi found that career development influenced turnover intentions. Based on this discussion and with little empirical study if at all that links career development with employee turnover intention in Kenya, the current study attempted to empirically examine how career development practices predict turnover intentions in teacher training colleges in Kenya in order to narrow the research gap.

\subsubsection{Performance Management}

Performance management focuses on planning and improving future performance through provision of regular and frequent dialogues between supervisors and individuals, or between teams about their performance and the way forward. According to Dimba (2009), performance management in organizations is widely acknowledged as very important in the achievement of various significant organizational outcomes related to organizational success such as productivity and the quality of employees, employee commitment and job satisfaction. Performance appraisal is the system that is used to assess the quality and quantity of an employees work in performance management (Abdullah, et al., 2012; Armstrong, 2006; Armstrong, 2009). Performance appraisals are used to support human resource decisions including promotions, terminations, training, and merit pay increase (Onyije, 2015). Shasuzzoha and Shumon (2012) argue that poor performance management is a major source of employee turnover intention. In support, Mohammed and Ibrahim (2014) in their quest to test the relationship between turnover intention and Human Resource Management practices in a non-Western context of the Palestine found out that performance management plays a very significant role in influencing nurses' level of turnover intention while Muhammad and Faizuniah (2015) using a sample of 270 respondents studied the relationship between human resource development factors, career growth and turnover intention. When organizational commitment was introduced as a mediating factor, the results revealed that performance management had a significant negative relationship with turnover intention. On the contrary, Muriithi, Ofunya and Kamau (2015) in their study on Effect of Strategic Human Resource Management on Teacher Turnover in Private Secondary Schools in Nyeri County, Kenya established that performance management had a positive relationship with employee turnover.

A study by Rafique and Muhammad (2016) with a sample of 120 respondents on Determinants of Teachers' Turnover Intention in Bahria Schools and Colleges at Karachi found that performance Management influenced turnover intentions. Given the review of extant literature performance management, it is worth noting that there is dearth of research that empirically investigates the influence of performance management on turnover intention in the Kenyan education system. Thus, the current study attempts to narrow this research gap by studying the influence of performance management on tutor turnover intentions in teacher training colleges in Kenya.

Nurun, Abu and Sahedur (2017) in their exploratory research seeking to examine and analyze the impact of Human Resource Management practices with special reference to job satisfaction and employee turnover at an Investment Corporation of Bangladesh found that performance management impacts on employee turnover. Data was analyzed using percentages and frequencies; association between socio-demographic characteristics and job satisfaction, as well as comparison of the level of job satisfaction between categories of the professionals was assessed for statistical significance using the 'chi-square' test of association. Factors influencing job satisfaction were also determined using the student t-test while the relationship between dimensions of job satisfaction was measured using Pearson correlations.

\subsection{Conceptualization and Hypotheses}

Based on the arguments drawn from the theoretical, conceptual and empirical literature reviewed, the study proposed a simple framework for predicting turnover intention among primary teacher training colleges in Kenya using the HRM practices discussed in the framework as presented in figure 1. 


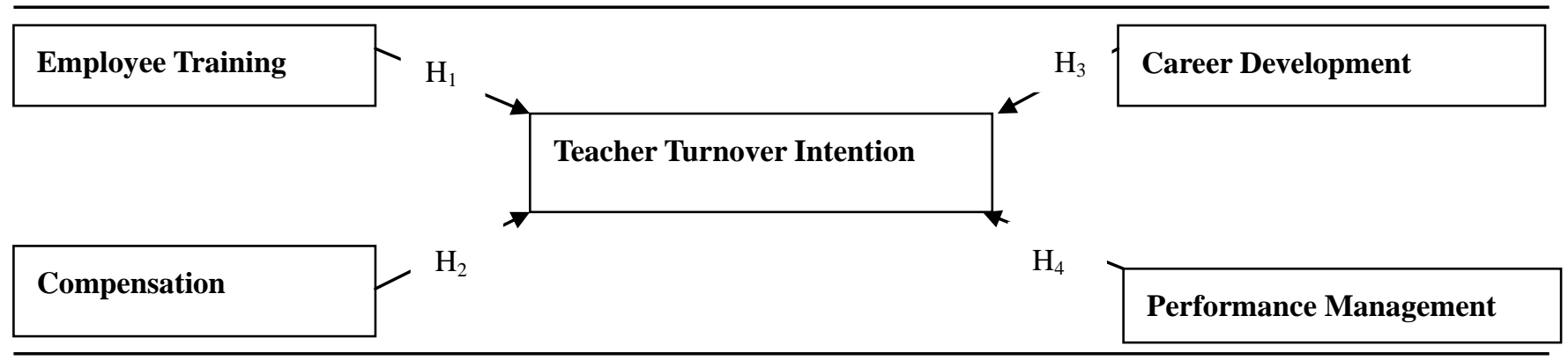

Figure 1. Conceptual framework linking hrm practices with turnover intentions

HRM practices (training, compensation, career development, performance management) were the Predictor variables that were used to predict tutor turnover intentions which was the criterion variable. Based on the reviewed literature, it was proposed that HRM practices will predict tutor turnover intentions among tutors in the selected PTTCs in Kenya as diagrammatically illustrated above. Therefore the study proposed four hypotheses as:

Hypothesis One: There is statistically significant influence of employee training on tutor turnover intentions in Primary Teacher Training Colleges in NMR in Kenya.

Hypothesis Two: There is statistically significant influence of employee compensation on tutor turnover intentions in Primary Teacher Training Colleges in NMR in Kenya.

Hypothesis Three: There is statistically significant influence of career development on tutor turnover intentions in Primary Teacher Training Colleges in NMR in Kenya.

Hypothesis Four: There is statistically significant influence of performance management on tutor turnover intentions in Primary Teacher Training Colleges in NMR in Kenya.

\section{Methodology}

\subsection{Research Design and Population}

The researchers adopted a positivist epistemological paradigm as recommended by Creswell, (1998) which is based upon highly structured methodology to enable generalization and quantifiable observations in order to evaluate the results with the help of quantitative statistical methods. Previous studies in Kenya on HRM have also adopted a similar orientation (Kilika 2012). In line with this paradigm, the study employed descriptive and explanatory research designs. Descriptive design describes, records, analyzes and reports conditions that exist or existed and the technique is widely used to obtain data useful in evaluating present practices and in providing the basis for decisionmaking while explanatory research design looks for explanations of the nature of certain relationships and investigates the cause effect relationship between variables (Kothari, 2009; Saunders, Lewis \& Thornhill, 2009).

The population of study comprised 1400 TSC tutors working in the 21 public teacher training colleges clustered into eight regions in Kenya. Multi stage sampling method was employed where the researchers started by use of stratified sampling in which all the colleges were grouped into the eight regions and purposive sampling method used to choose the colleges in the Nairobi Metropolitan Region. With the help of the approach by Krejcie and Morgan (1970) for determining sample size from a definite population, the researchers selected a sample size of 152 respondents. The respondents were tutors in the colleges (the employees) and the principals of the colleges (representing management).

\subsection{Research Data and Analysis}

Two types of questionnaires were used to obtain primary data from both the principals and the tutors. The questionnaires consisted of three sections that were designed to obtain data on demographic characteristics of the respondents, HRM practices and turnover intentions. The research instrument was structured on a five point likert scale on the sections measuring both the independent and dependent variables. The researchers dropped the questionnaires to the respective colleges and collected them after two weeks.

The Statistical Package for Social Sciences software (SPSS, version 20) was used to analyze the collected data. Descriptive statistics were used to assess the variable characteristics where frequencies, percentages, means and standard deviations were used to interpret the results. Inferential statistics were carried out using multiple regression 
analyses to establish the influence of the dependent variables under study on the dependent variable. Several diagnostic tests were conducted to ascertain that the data conformed to the basic assumptions of regression analysis and that the findings and conclusions of the study are not invalidated by nonconformance to the assumptions of regression analysis. The findings showed that the data was normally distributed and that there was no evidence of multicollinearity and heteroskedasticity.

\section{Research Findings}

\subsection{Respondents Characteristics}

After data cleaning, screening and verification 113 questionnaires out of 152 were found complete representing $74.3 \%$ response rate. A summary of the respondents characteristics are shown in the table 1 . The table shows that female tutors comprised $57.5 \%$ while male tutors comprised $42.5 \%$. The principals were equally distributed with $50 \%$ being male and $50 \%$ being female, $60.2 \%$ of the tutors were above 45 years old while all the four principles were above 55 years old. $99.1 \%$ of the tutors had attained a bachelor's degree and above whereby $54 \%$ of the tutors had a master's degree and above. On the contrary $75 \%$ of the principals hold a Bachelor Degree while $25 \%$ hold a $\mathrm{PhD}$. 54\% of the tutors had worked in the colleges for over 6 years while $46 \%$ had worked for less than 6years. $75 \%$ of the principals had worked in college for a less than 5 years while $25 \%$ had served for over 16 years. The majority of the tutors occupied the middle job groups $(\mathrm{M} \& \mathrm{~N})$ at $69 \%$ and a few on the extreme ends whereby $59.3 \%$ of the tutors had worked in their current job group for less than 5 years while $41.7 \%$ had worked for over 5 years. On the other hand, $50 \%$ of the principals had served in their current job group for less than 5 years while $50 \%$ had worked in their current job group for over 16 years.

Table 1

\begin{tabular}{|c|c|c|c|c|}
\hline & Principals & & Tutors & \\
\hline College & Frequency & Percentage & Frequency & Percentage \\
\hline Kitui & 1 & 25 & 38 & 33.6 \\
\hline Thogoto & 1 & 25 & 28 & 24.8 \\
\hline Machakos & 1 & 25 & 33 & 29.2 \\
\hline Narok & 1 & 25 & 14 & 12.4 \\
\hline Total & 4 & $100 \%$ & 113 & $100 \%$ \\
\hline \multicolumn{5}{|l|}{ Sex } \\
\hline Male & 2 & 50 & 48 & 42.5 \\
\hline Female & 2 & 50 & 65 & 57.5 \\
\hline Total & 4 & 100 & 113 & $100 \%$ \\
\hline \multicolumn{5}{|l|}{ Age } \\
\hline $26-35$ & 0 & 0 & 7 & 6.2 \\
\hline $36-45$ & 0 & 0 & 38 & 33.6 \\
\hline $46-55$ & 0 & 0 & 59 & 52.2 \\
\hline $56-60$ & 4 & 100 & 9 & 8 \\
\hline Total & 4 & 100 & 113 & $100 \%$ \\
\hline \multicolumn{5}{|c|}{ Highest Level of Education } \\
\hline Diploma & 0 & 0 & 1 & .9 \\
\hline Bachelor's Degree & 3 & 75 & 51 & 45.1 \\
\hline Masters Degree & 0 & 0 & 58 & 51.3 \\
\hline $\mathrm{PhD}$ & 1 & 25 & 3 & 2.7 \\
\hline \multirow{2}{*}{\multicolumn{5}{|c|}{ Years worked in college }} \\
\hline & & & & \\
\hline $0-5$ & 3 & 75 & 52 & 46.0 \\
\hline $6-10$ & 0 & 0 & 26 & 23.0 \\
\hline $11-15$ & 0 & 0 & 19 & 16.8 \\
\hline 16 and above & 1 & 25 & 16 & 14.2 \\
\hline Total & 4 & 100 & 113 & 100 \\
\hline \multicolumn{5}{|c|}{ Current job group } \\
\hline K & 0 & 0 & 2 & 1.8 \\
\hline
\end{tabular}




\begin{tabular}{|c|c|c|c|c|}
\hline $\mathrm{L}$ & 0 & 0 & 25 & 22.1 \\
\hline M & 0 & 0 & 53 & 46.9 \\
\hline $\mathrm{N}$ & 2 & 50 & 25 & 22.1 \\
\hline $\mathrm{P}$ & 1 & 25 & 6 & 5.3 \\
\hline Q & 1 & 25 & 1 & .9 \\
\hline Others $(\mathrm{R})$ & 0 & 0 & 1 & .9 \\
\hline Total & 4 & 100 & 113 & 100 \\
\hline \multicolumn{5}{|c|}{ Years worked in current job group } \\
\hline $0-5$ & 2 & 50 & 67 & 59.3 \\
\hline $6-10$ & 0 & 0 & 34 & 30.1 \\
\hline $11-15$ & 0 & 0 & 11 & 9.7 \\
\hline 16 and above & 2 & 50 & 1 & .9 \\
\hline Total & 4 & 100 & 113 & 100 \\
\hline
\end{tabular}

\subsection{Descriptive Characteristics}

The characteristics of the variables under study were summarized through measures of central tendency (mean) and measures of dispersion (standard deviation) and the findings are presented in table 2.

Table 2

\begin{tabular}{llllll}
\hline HRM practices & $\begin{array}{l}\text { Reliability } \\
\text { (系 Score) }\end{array}$ & $\begin{array}{l}\text { Principals } \\
\text { Aggregate } \\
\text { mean }\end{array}$ & $\begin{array}{l}\text { Std. } \\
\text { deviation }\end{array}$ & $\begin{array}{l}\text { Tutors } \\
\text { Aggregate } \\
\text { mean }\end{array}$ & $\begin{array}{l}\text { Std. } \\
\text { deviation }\end{array}$ \\
\hline Employee Training & 0.875 & 2.3125 & 1.02706 & 2.3019 & 1.11702 \\
Employee Compensation & 0.720 & 2.4583 & 1.3880 & 2.4363 & 1.4349 \\
Career Development & 0.940 & 2.0712 & 1.2572 & 2.1166 & 1.22269 \\
Performance Management & 0.870 & 2.64286 & 1.79975 & 2.9904 & 1.119897 \\
Turnover Intentions & 0.755 & 2.85 & 1.3604 & 3.3803 & 1.41029 \\
\hline
\end{tabular}

The respondents were asked to rate their agreement or disagreement on various statements on the various HRM practices on a five point likert scale ranging from strongly disagree to strongly agree. The overall aggregate mean for training was $M=2.3019 ; S d$. $=1.11702$ for the tutors and $M=2.3125 ; S d$. $=1.02706$ for the principals. This implies that on average the tutors and the principals disagreed on the various statements that stated that that colleges offer training to its tutors. Compensation scored a mean of $M=2.43635$; $S d=1.43491$ for the tutors and $M=2.45833$; $S d$. $=1.338807$ for the principals. This implies that in general the tutors and the principals disagreed that the college offers compensation to its tutors. The aggregate mean for career development stood at $M=2.1166 ; S d$. $=1.22269$ for the tutors and $M=2.07142 ; S d .=1.25728$ indicating that the tutors and the principals disagreed that there is career development in PTTCs. Performance management had the highest aggregate mean of $M=2.99 S d .=1.119897$ as compared to the other Human resource management practices employed in this study. Lastly, the principals and the tutors were neutral on turnover intentions posting a mean of $2.85 ; S d .=1.3604$ and $M=3.3803 ; S d$. $=1.41029$ respectively.

\subsection{Test of Hypotheses}

The test of hypotheses was performed using multiple regression analysis and the results were interpreted using the $\mathrm{R}^{2}$, $\beta$ values and the $p$ values at $p<0.05$ significance level. The results from the regression are presented in the table 3 .

The results from the ANOVA test show an F value of 10.968 with a significance level of 0.000 which is far much lower than the confidence level of 0.05 , hence the statistic recorded is significant. The implication is that the regression analysis model used to test how HRM Practices predict Turnover Intentions is statistically significant. The $\mathrm{R}$ Square value of 0.289 and adjusted $\mathrm{R}$ square value of 0.263 mean that only $28.9 \% \%$ of the variation in tutor turnover intention in the PTTCs has been explained by the independent variables. The remaining $71.9 \% \%$ of the variance is explained by other variables not included in this study. 
Table 3

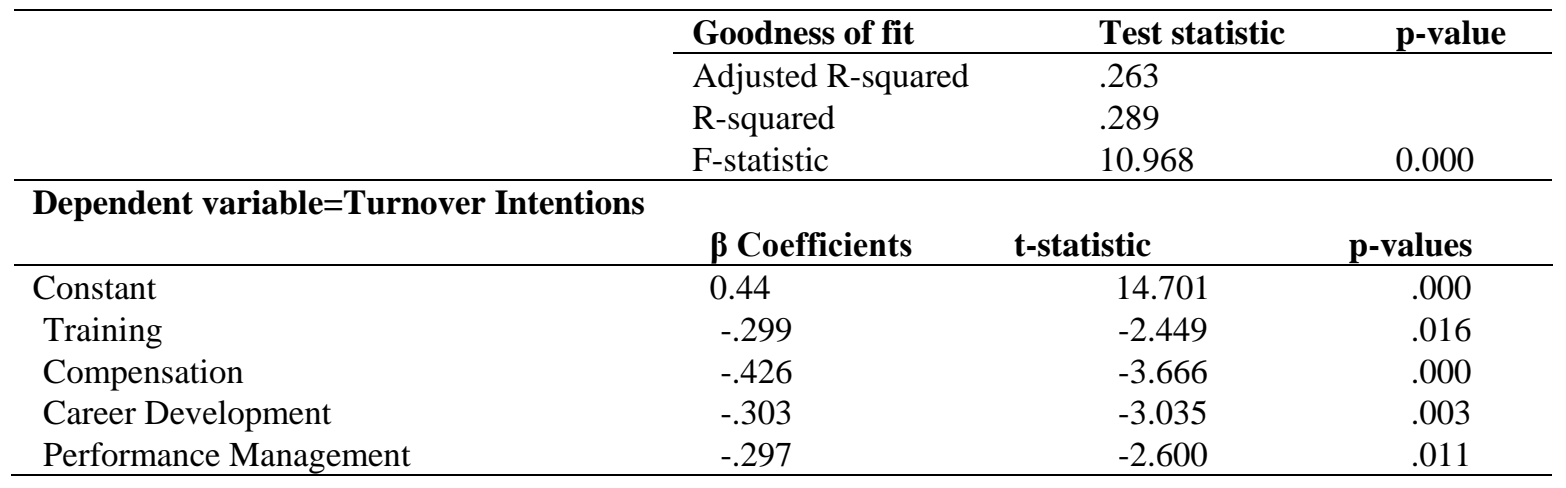

The regression results for hypothesis one indicated that $\boldsymbol{\beta}=\mathbf{- 0 . 2 9 9}$ at $\mathrm{p}<0.05$ level of significance the hypothesis is supported implying that training has a significant negative influence on tutor turnover intentions in primary teacher training colleges and therefore a predictor of tutor turnover intention. The regression results for hypothesis two indicated that $\boldsymbol{\beta}=\mathbf{- \mathbf { 0 . 4 2 6 }}$ at $\mathrm{p}<0.05$ level of significance, the hypothesis is supported implying that compensation negatively influences tutor turnover intentions in primary teacher training colleges in Kenya. The regression results for hypothesis three indicate that $\boldsymbol{\beta}=\mathbf{- \mathbf { 0 . 3 0 3 }}$ at $\mathrm{p}<0.05$ level of significance, the hypothesis is supported implying that career development significantly and negatively influence tutor turnover intentions in primary teacher training colleges. The regression results for hypothesis four showed that $\beta=\mathbf{- 0 . 2 9 7}$ at $\mathrm{p}<0.05$ level of significance. Thus, the hypothesis was supported implying that performance management had a negative significant influence on tutor turnover intentions in primary teacher training colleges. Given the $\beta$ values for the independent variables, the contribution of HRM practices towards minimizing turnover intention among tutors in PTTCs in Kenya is relatively low.

\section{Discussions and Implications for Theory}

In view of the findings reported, the researchers interpreted these findings in relation to the literature reviewed and the characteristics of the sector. The discussions are summarized on the basis of the research hypotheses tested and reported in the paper.

The first hypothesis of the study sought to investigate the influence of employee training on tutor turnover intentions in primary teacher training colleges in Kenya whereby a hypothesis stating that training has significant influence on tutor turnover intentions was tested and measured. The conclusions arrived at on this hypothesis can be explained on several grounds. From the theoretical perspective, the study noted that the adoption of certain best human resource practices such as training would result into improved employee attitudes and behaviors which result in employee retention and that, employees follow psychological and behavioral paths when quitting employment. The researchers observe that the findings of the study raise two implications touching on the state of employee training as an HRM practice by an organization on one hand and its psychological consequences on the part of the employee on the other hand. The first implication arises from the fact that the descriptive results that showed that Training needs assessment (TNA) is rarely practiced and that certain best HRM practices leveraging on the TNA outcomes have not been adopted, the situation has tended to influence the psychological state of the tutors resulting in the prevailing state of turnover intentions. Secondly, even though TSC has devolved its functions to county and sub county levels, the actual HRM practice has not been delegated to the units that implement the HRM practice in the daily management of institutions in the education sector. In terms of SHRM propositions and expectations of vertical and horizontal integration, the lack of delegation to the principals gives rise to the continued lack of integration because the principal is required to carry out both line and staff functions in each college.

The second hypothesis of the study sought to investigate the influence of employee compensation on tutor turnover intentions in primary teacher training colleges in Kenya whereby a hypothesis stating that compensation has significant influence on tutor turnover intentions. Based on the conclusions on hypothesis two, the researchers observed that the findings raise two implications. First the implication pointing at relevant employee related attitudes considered essential for HRM by the behavioral scientists. Experts in behavioral science cite the role of three types of attitudes: job commitment, employee turnover and job satisfaction in employees which can be provided for by compensation. These psychological consequences arise from lack of an exchange relationship between the employer and the employee which emphasize quantifiable exchanges between the two parties. When employees perceive that 
the exchange is not fair, this then leads to the current employee psychological state of turnover intentions as shown in this study.

The third hypothesis of the study sought to investigate the influence of career development on tutor turnover intentions in primary teacher training colleges in Kenya whereby a hypothesis stating that career development has significant influence on tutor turnover intentions. The researchers observed that the study findings bring out the implications concerning the important role played by the principals as the TSC agents in the implementation of the HRM functions in their colleges for they are the immediate supervisors who interact on daily basis with the tutors. Owing to the argument that career development is an approach to HRM which aims at shaping employee attitudes by forging psychological links between organizational and employee goals, and promotes the goals of both employees and employer, when not provided it is likely to account for a cause of dissatisfaction in the said employee. This dissatisfaction causes the employees to consider leaving working or to continue working without enthusiasm resulting in the prevailing state of tutor turnover intentions. The study findings also bring out an implication touching on the importance of empowering the principals to recommend to the TSC the tutors who have an exemplary performance record for promotion. This is because the principals are constantly in touch with the tutors, hence better placed in knowing those tutors who perform well and should be promoted.

The fourth hypothesis of the study sought to investigate the influence of performance management on tutor turnover intentions in primary teacher training colleges in Kenya whereby a hypothesis stating that performance management has significant influence on tutor turnover intentions. Regarding the conclusion arrived at in hypothesis four, the findings raise the implication touching on the state of performance management as a very crucial HRM practice in the achievement of various outcomes related to organizational success, including employee commitment and employee retention. Performance management acts as the basis for the other HRM practices such as training, career development and compensation. Owing to the fact that performance management is rarely practiced in colleges and being the basis on which to consider the other HRM practices as providing a synergistic effect of combined practices, popularly called "bundles" which represent combinations of interrelated and internally consistent HR practices complementing each other and exhibiting greater and more direct influence on organizational competitive advantage, this situation has tended to influence the psychological state of the tutors leading to the prevailing state of turnover intentions. Further, the TSC under the new constitution (2010) is responsible for Performance Appraisal of its members. In spite of the TSC's performance appraisal system objectives being providing feedback, identifying training needs, clarifying roles and responsibilities and determining how to allocate rewards among others; these objectives were missing as far as the colleges are concerned. This disparity between the objectives of the TSC and the colleges led to tutor turnover decisions as evident in the current study.

\section{Conclusions and Recommendations for Future Research}

The results reported from the descriptive results on the independent variables recorded a low mean of 2 which was interpreted to mean that the HRM practices investigated in the study are rarely practiced in PTTCs. Tutor turnover intentions which was the dependent variable recorded an aggregate mean of 3.4 which was interpreted as an indication of being at the level of indifference on turnover behavior. In spite of this indifference, the tutors agreed that they were furthering their education with an intention of finding greener pastures outside teaching. Further, training, compensation, career development and performance management significantly and negatively predicted turnover intention.

Based on the study findings, the study makes three conclusions. First, HRM Practices of training, compensation, career development and performance management are applied in PTTCs to a low extent. Secondly, as currently practiced, these practices are relevant predictors of tutor turnover intentions in teacher training colleges in Nairobi Metropolitan Region in Kenya. Therefore, there is need for the employer (Teachers Service Commission) to provide up to date HRM practices in teacher training colleges for better tutor management. Thirdly, even though the HRM practices are important predictors of turnover intention among tutors in PTTCs in Kenya, their level of influence on turnover intention is low owing to the low level of devolution of power to practice HRM function on the part of the principals. The findings and the conclusions of the study are limited by the fact that the study did not consider the role of the tutor demographics as suggested by some of the empirical studies reviewed. Secondly, the study did not consider the role of the context of the practice of HRM especially the contingent role of the TSC policy that restricts the scope of the activities of the principals in practicing HRM functions in colleges. The authors are of the view that future research can consider the moderating effect of these demographic and contextual factors on the relationship between HRM practices and turnover intentions. 


\section{References}

Foon, Y., Chee-Leong, T., \& Osman, L. (2010). An Exploratory Study on Turnover Intention among Private Sector Employees. International Journal of Business and Management, 5(8). Retrieved from https://www.researchgate.net/.../45266852

Gong, Y., Chang, S., \& Cheung, S.Y. (2010). High Performance Work System and Collective OCB: A Collective Social Exchange Perspective. Human Resource Management Journal, 20, 119-137. https://doi.org/10.1111/j.1748-8583.2010.00123.x

Homans, G.C. (1958). Social behavior as exchange. American Journal of Sociology, 63, 597-606. https://doi.org/10.1086/222355

Kilika, J.M. (2012). Institutional context, collaboration, human resource development infrastructure and performance of universities in Kenya. Unpublished Ph. D Thesis. School of Business, University of Nairobi.

Kilika, J.M., K’Obonyo, P.O., Ogutu, M., \& Munyoki, J.M. (2013, April). Human Resource Development Drivers for University-Industry Collaboration: Empirical Evidence from Universities in Kenya. International Journal of Education and Research, 1(4). Retrieved from http//www.ijern.com/April-2013.php

Kilika, J.M., K'Obonyo, P.O., Ogutu, M., \& Munyoki, J.M. (2016). The Mediating Role of University Industry Collaboration on the Relationship between Human Resource Development Infrastructure and Performance of Universities in Kenya. Asia Pacific Journal of Advanced Business and Social Studies, 2(1), 129-148. Retrieved from http://journal-of-advanced-business-and-social-studies\#

Masinde, C., Kwasira, J., \& Kiprotich, P.C. (2014). Assessment of Human Resource Management Practices on Employee Retention in Kenya, A Survey of Private Secondary Schools in Nakuru Town. International Journal of Human Resource Management and Research, 4(6), 53-68, Retrieved from www.tjprc.org/.../2-34-1415430944-ABS\%20-\%205.\%20Human\%20Resources\%20-

Mbugua, G.M. (2015). Relationship between Strategic Human Resource Management practices and Employee. Retention in Commercial Banks in Kenya: unpublished PhD Thesis, Jomo Kenyatta university.

Mrope, G., \& Bangi, Y. (2013). Examining the Influence of Management Practice and Attitudes on Employee Turnover: A Case of Kibaha District Council .The International Journal of Business \& Management, 2321-8916. Retrieved from www.theijbm.com

Muhammad, A., Muhammad, M.G., Easha, M., \& Sadia, H. (2013). The Impact of Perceptions of Training on Employee Commitment and Turnover Intention: Evidence from Pakistan. International Journal of Human $\begin{array}{llll}\text { Resource } \quad \text { Studies, } & \text { 2162-3058. } & \text { Retrieved from }\end{array}$ www.macrothink.org/journal/index.php/ijhrs/article/download/2924/10256

Muhammad, S.N., \& Faizuniah, P. (2016). The relationship between human resource development factors, career growth and turnover intention: The mediating role of organizational commitment. Management Science Letters, 6, 157-176 Retrieved from https://www.researchgate.net/.../290511468

Muriithi, C.G., Ofunya, F.A., \& Kamau, R. (2015). Effect of Strategic Human Resource Management on Teacher Turnover in Private Secondary Schools in Nyeri County. Journal of Poverty, Investment and Development, 11, 2422-2846. Retrieved from https://www.coursehero.com >

Mutiso, C., \& Kilika, J.M. (2017). Using Human Resource Management Practices to predict Quality Service Delivery: Case of Public Secondary Schools in Kenya. International Journal of Business and Management, 12(10), 121-131. https://doi.org/10.5539/ijbm.v12n10p121

Ng'ethe, J.M, Iravo, M.E., \& Namusonge, G.S. (2012). Determinants of Academic Staff Retention in Public Universities in Kenya: Empirical Review. International Journal of Humanities and Social Science, 2(13) Retrieved from www.ijhssnet.com/journals/Vol_2_No_13_July_2012/22.pdf

Nyambura, J.K. (2012). Factors Influencing Teacher Turnover in Public Secondary schools: A Case of Makadara District, Nairobi County. Unpublished Masters Research Project. Kenyatta University.

Oduor, A. (2015). Why nearly half of Kenyan teachers want to leave their profession Retrieved from http://www.standardmedia.co.ke/article/2000150713/

Rafique, A.K., \& Muhammad, I.Q. (2016). Determinants of Teachers' Turnover Intention in Bahria Schools and Colleges at Karachi .Journal of Business Studies, 1(12), 198-218. 
Raigama, R.N. (2010). Do HRM practices impact Employee Satisfaction, Commitment or Retention? Empirical studies of Sri Lankan Public Sector Banks. Retrieved from https://brage.bibsys.no/.../Raigama\%20Rathnaweerage\%20Neelamani\%20Thanuja\%20

Shamsuzzoha, A.H.M., \& Rezaul, H.S. (2007). Employee Turnover- a Study of its Causes and Effects to Different Industries in Bangladesh. Manufacturing Engineering, 6(3) 64-68. Retrieved from https://pdfs.semanticscholar.org/7060/d67fb0f7b578fb91aae0824f0ebccf76e7a6.pd

UNESCO. (2012). Systematic monitoring of education for All. United Nations Educational, Scientific and Cultural Organization, UNESCO.

UNESCO. (2015).World teachers day. United Nations Educational, Scientific and Cultural Organization, UNESCO.

Victor ,Y., Patrice, J., \& Karine, L. (2010). The Influence Of Human Resource Management Practices On Employee Voluntary Turnover Rates In The Canadian Non Governmental Sector .Industrial and Labor Relations Review, 63(2), 228-246. https://doi.org/10.1177/001979391006300203

Waititu, G.M. (2013). An Analysis of Factors Influencing Turnover of Teachers in Public High Schools in Limuru District, Kenya.Unpublished Masters project.

Walumbwa, F.O., Orwa, B., Wang, P., \& Lawler, J. (2005). Transformational leadership, organizational commitment, and job satisfaction: A comparative study of Kenyan and U.S. financial firms. Human Resource Development Quarterly, 16(2), 235-256. https://doi.org/10.1002/hrdq.1135 